\title{
Coffee elite in Colombia and its participation in the Foreign Policy during the first half of the 20th century
}

Elite do café na Colômbia e sua participação na Politica Externa durante a primeira metade do século $X X$

Yulieth E. Martínez V. ${ }^{1}$

\begin{abstract}
:
This paper aims to bring some reflections about the participation of the Colombian coffee elite, grouped in the National Federation of Coffee Growers (NFCG), in the orientation of country 's foreign trade policy during the first half of the 20th century, when coffee's share in exports reached levels of $80 \%$.
\end{abstract}

Keywords: Colombia, Coffee Elite, Foreign Policy.

\section{Resumo:}

Este trabalho tem como objetivo trazer algumas reflexóes sobre a participação da elite cafeicultora da Colômbia, aglomerada na Federação Nacional de Cafeicultores (FNC), na orientação da politica de comercio exterior do pais na primeira metade do Século XX, quando a participação do café nas exportaçóes chegou a niveis de $80 \%$.

Palavras chave: Colômbia, Elite do Café, Politica Externa.

\footnotetext{
1 Master student in Political Science from the Federal University of Minas Gerais (UFMG) Belo Horizonte- Brazil, Specialist in "South's Epistemologies" by the Latin American Council of Social Sciences (CLACSO) and International Business Professional from Universidad del Magdalena (Colombia). Belo Horizonte/Brazil. ORCID: https://orcid.org/0000-0003-2047-766 (iD)
} 


\section{Introduction: Colombia as a "Coffee Maker"}

\author{
"Without coffee, the world as we \\ know it would not exist". Catherine \\ M. Tucker, 2017
}

The role of coffee in Colombia goes beyond a simple commodity. Its importance in the socio-economic development of the country is undeniable and its transcendence in Colombia's international projection is a fact.

Historically, Colombia has been part of the main coffee producers in the world. Nonetheless, currently, this country is more recognized by the quality of its coffee than of its production volume. In figures, Colombia ranks third place in world coffee production, after Brazil and Indonesia, according to the Coffee Market Report for 2018. It registered an estimated production of 14.19 million bags of $60 \mathrm{~kg}$ for the year 2017, of which 12.98 million bags were destined for export, according to official figures from the National Federation of Coffee Growers (NFCG).

The emergence of coffee in Colombia dates to the beginning of the eighteenth century with the arrival of the Jesuits (CARDÉNAS, 1993). Slowly and through the encouragement of its cultivation, it became the main agricultural product that made possible the colonization of land and also allowing the expansion of the population into the national territory (FALS BORDA, 2008). Agriculture was assumed in Colombia as the way in which "production is organized and the land is appropriated" (KALMANOVITZ, 2003, p. 95), positioning itself in a predominant place of the economic and development model which is deepened through the centralization project unveiled and consolidated in the last decades of the 19th century (KALMANOVITZ, 2003).

In this context, the present work assumes that economic development can be an import- ant aspect for interpreting large social, cultural and political changes (INGLEHART; WELZEL, 2005) by being part of the evolutionary process of a country, including its international dimension. Therefore, coffee, that is, the economic development determined by it and the social structures that were built around it - more specifically the formation of a coffee elite - is assumed as the explanatory variable that will allow us to understand economic development in Colombia and its relation to the place that this country occupied on the international scene during the first half of the 20th century. Considering that in fact, as Inglehart and Welzel (2005, p. 28) suggest, "the interrelation between the international context, collective actors, and social forces is important", this paper seeks to understand how the coffee elite, clustered in the NFCG, participated in the definition of foreign policy, specifically with regard to foreign trade, during the coffee boom in Colombia in the first half of the 20th century. To this end it was carried out a bibliographic survey and documentary analysis of public opinion articles, official documents, general reports and scientific papers in order to identify central elements of this process and, above all, to assimilate the correspondence between the coffee elite and Colombia's foreign trade policy, according to information recorded in these documentary files.

The structure of the article is composed of three moments. The first moment, sought to briefly address the emergence of the National Federation of Coffee Growers, considering the relevance that this organization has for the coffee industry in the country and its relations with the coffee producing elite, which in the beginning had direct links with the exercise of politics in Colombia. Subsequently, an attempt was made to identify where the elite was located in the organizational structure of the NFCG and how it was constituted in the different 
instances at local and regional level, until reaching the national level. Finally, they were indicated some forms of participation of the coffee elite, mainly those related with people located in the places of decision of the NFCG, in the orientation of Colombian foreign trade policy in the first half of the 20th century.

The social, political, cultural and economic scenario of a country is undoubtedly the background for the formulation of its public policies, including its foreign policy. The latter is not entirely different from domestic policies, if we think that "internal, external and international policies make up a continuum in the decision-making process"(RATTON SÁNCHES et al, 2006, p. 125), since, as stated by Putman (1988, p. 427), "domestic politics and international relations are often somehow entangled". Therefore, Foreign policy is indeed a public policy, with the specificity that is implemented outside state borders, which can lead to a considerable distance between objectives and results (SALOMÓN; PINHEIRO, 2013). In this sense, the foreign policy of coffee is closely related to the internal public policies formulated at that time. They were determinants in Colombia's future trajectory both nationally and internationally because, after all, what happens in the territorial surroundings of states will stimulate them to provide answers to the 'outside world (LOPES; FARIA; SANTOS, 2016, p.4).

\section{The Emergence of the National Federation of Coffee Growers (NFCG) and the Relation With its Founder Members}

With the gradual growth of the production and export of coffee in the first decades of the twentieth century was created in Colombia the National Federation of Coffee Growers (NFCG) or FEDE-
CAFE - as it is also known - in the year of 1927 , curiously, just 4 years later than the creation of Banco de la República - the Central Bank of Colombia (CARDÉNAS, 1993).

This initiative arises from the need to organize the action of coffee producers through an organized collectivity, that is, a trade union organization separated from the former Colombian Farmers Society (CFS) -founded around at 1870, in an effort to bring together the different levels of the coffee production chain onto the same institution. In this sense, the NFCG was configured as an interest group vis-à-vis the Colombian government, which allowed its members and mainly its managers to discuss and conceive "their own management instruments" (CÁRDENAS, 1993 , p. 5). Understanding as an interest group "a formally organized association that engages in activities aimed at influencing the decisions to be made by governmental authorities" (SALISBURY, 1975, p. 175).

The foundation of the NFCG is given in the framework of the II National Coffee Congress that took place in Medellin from June 21 to 27 at 1927, in which "the first statutes of the entity were established, and a national committee was elected to work from Bogotá" (SAETHER, 1999, p. 146). Nevertheless, an important fact of the creation of the NFCG, which is not found in its official rhetoric, is that this organization was promoted by landowners, politicians, and merchants related with the Conservative Party with a big influence in their regions or through the nation.

To substantiate the above, we will rely on a review made by Saether (1999) of the participants who attended the conference, based on four attendance lists published on different dates and with a different number of participants in the Coffee Magazine, an official organ of the Federation (see table 1). 
Chart 1- Delegates to the II National Congress held between June 21 and 27, 1927. ${ }^{2}$

\begin{tabular}{|c|c|c|c|}
\hline \multicolumn{2}{|r|}{ Delegates } & Biographical information & Region Represented \\
\hline 1 & Carlos E. Restrepo & Former President of Colombia of Medellín & Valle \\
\hline 2 & Alejandro Múnera & Conservative Congressman of Medellín & Nariño \\
\hline 3 & Mariano Ospina Pérez & Conservative Senator of Medellín & Antioquia \\
\hline 4 & Manuel Valencia & There is not information & Magdalena \\
\hline 5 & Luis Heiniger & Merchant and landowner of Antioquia & SA de Antioquia \\
\hline 6 & Reinaldo Bótero & Merchant of Medellín & Magdalena \\
\hline 7 & Joaquin Santamana & There is not information & Antioquia \\
\hline 8 & Fransisco Luis Olarte & Merchant and landowner of Santa Marta & SA de Santa Marta \\
\hline 9 & Gabriel Jaramillo M. & There is not information & Caldas \\
\hline 10 & Nicanor Restrepo & Landowner of Antioquia & Chocó \\
\hline 11 & Pedro Bernal & Merchant and landowner of Caldas & SA de Manizales \\
\hline 12 & Rafael Ospíne Pérez & Merchant and landowner of Antioquia & Chocó \\
\hline 13 & Julio C. Gaitán & A representative of the national government & Gobierno Nacional \\
\hline 14 & Daniel Uribe Bótero & There is not information & Chocó \\
\hline 15 & Santiago Rozo & $\begin{array}{l}\text { Counsel and lawyer of Pedro Nel Ospina } \\
\text { and diplomat }\end{array}$ & Cundinamarca \\
\hline 16 & Ric. Greiffenstein & Merchant of Medellin & Bolívar \\
\hline 17 & Carlos Mallarino & Merchant and landowner of Tolima & Tolima \\
\hline 18 & Gonzalo Mejía & Merchant of Medellin & Bolívar \\
\hline 19 & Ricardo Olano & There is not information & Cauca \\
\hline 20 & Enrique Mejía O. & Merchant of Medellin & Cundinamarca \\
\hline 21 & Juan Medina R. & There is not information & Boyacá \\
\hline 22 & Carlos E. López & Merchant of Medellin & Boyacá \\
\hline 23 & Pedro Estrada G. & Merchant of Medellin & Huila \\
\hline 24 & Carmelo Nuñez & There is not information & North of Santander \\
\hline 25 & Roberto Carreño & Landowner of Santander & South of Santander \\
\hline 26 & Jorge Villamil & Landowner of Huila & Huila \\
\hline 27 & A. Carda Cadena & Landowner of Santander & South of Santander \\
\hline 28 & José Luis López & Merchant of Medellín & Nariño \\
\hline 29 & Gustavo Echeverríe & Government Representative & Gobierno Nacional \\
\hline 30 & Epifanio Montoya & Merchant and landowner of Medellín & not found (n.f.) \\
\hline 31 & Gregorio Agudelo & There is not information & n.f. \\
\hline 32 & Heliodoro Angel & There is not information & n.f. \\
\hline
\end{tabular}

Source: Table made based on the information withdrawn from SAETHER, 1999, p. 146-148.

Thanks to biographical sources the author characterized the profile of participants and conclude that the meeting had 32 participants in total of which 15 "were from Antioquia or had strong ties with the Antioquia coffee industry, despite that many of them figure as representatives of other departments" (SAETHER, 1999, p. 147). In other words, close to $50 \%$ of the founders of the Federation had a clearly established and predominant regional link with Antioquia, which places this region as an important axis for the expansion of the coffee industry, becoming over the years as the coffee zone for excellence.

2 This chart was synthesized and adapted to the demands of this work. Thus, the delegates of Antioquia who were registered as representatives of this department were highlighted with gray, the participants who had biographic links with Antioquia but who were representing other departments were highlighted in blue. And finally, participants belonging to the diplomatic sphere were highlighted in yellow.
Another important finding that Saether (1999, p. 147) points out is that, apparently, most of the participants not only had ties to the Antioquia coffee industry but were part of the group of people close to the Ospina family, the conservative party and the Society of Farmers of Antioquia. This situation contributes to elucidate how Mariano Ospina Pérez, an Antioqueño ${ }^{3}$, grandson of former President Mariano Ospina Rodríguez -founder of the conservative party- and nephew of another former President Pedro Nel Ospina, becomes General Director of the NFCF between 1930 -1934 and later follows the family tradition and becoming president of Colombia between 1947-1950. Another fact that draws attention about the Saether's systematization

\footnotetext{
3 Expression to name a person from the department of Antioquia in Colombia.
} 
(1999) is the presence of Santiago Rozo, counselor and lawyer of former President Pedro Nel Ospina, who at this moment was part of the Colombia diplomatic corps and serving as honorary Vice Consul in Manaus since $1922^{4}$ (BECERRA, 2007).

Finally, regarding the financing structure, the NFCG was initially supported by a tax on coffee exports (DURÁN, 2008) which was granted thanks to the approval of law 76 of 1927 by Republic's Congress which gave to the National Federation of Coffee Growers the authority to administer and manage all its revenues, that is, it granted the NFCG "the corporate tax or parafiscal resources" (VARGAS, 1996, p. 12). This prerogative, unique in history, is one of the main aspects that contributed to the strengthening of the NFCG considering that the transferred value was not negligible since the share of coffee in the country's total exports reached levels of $80 \%$ in the first half of the 20th century (URRUTIA et al, 2000).

The foregoing serves as an example to understand how economic aspects are related to the foreign policy of a country. In the case of Colombia, as it will be detailed below, diplomacy from the beginning had a strong economic side, which might allow us to talk about economic diplomacy ${ }^{5}$, as in, the economic preponderance of coffee made the country prepare its diplomatic corps to assist, in the realization of objectives linked to the projection of Colombia through the valorization of coffee internationally. Thus, contemporary authors such as Bayne and Woolcok (2011) understand economic diplomacy as the "process of international economic decision-making" (WOOLCOCK; BAYNE,

4 According to Becerra (2007), Santiago Rozo served as Consul General of Manaus in the first decade of the twentieth century, replacing Heliodoro Jaramillo.

5 The third section of this article will discuss the specific use of economic diplomacy made by Colombia, called coffee diplomacy.
2011 , p. 1), which originally is limited to the measures taken in the border, operating increasingly 'within the border' and influencing national policy.

\section{Coffee Elite in Colombia and its Connection With the NFCG's Organizational Structure}

The organizational structure of the NFCG was constituted as a trade union organization, with instances at the different levels of the territorial structure, going from the local level to the national level. Thus, the Municipal Committees also called Local Boards are the first unit of the Federation. These are followed by the Departmental Committees or Regional Boards, which are composed of members chosen by the municipal committees and, in turn, this second unit delegates representatives to participate in the National Congress of Coffee Growers -the highest authority of the Federation-. These committees also propose its main delegates to be part of the Steering Committee which is the fundamental organ in the definition of policies for the sector, because their members constitute together with the government representatives: The National Committee of Coffee Growers, considered as the "instance of conciliation of the coffee policy with the National Government" (CÁRDENAS, 1993, p.6). However, the Federation also has an administrative structure with several corporate units that are divided into strategic business units and support units. These units were responsible for promoting the coffee activity and make viable the implementation of policies established by the Steering Committee as result from the negotiations with the government.

The organizational information of the NFCG is important for the present work insofar as it allows us to understand how the decision-making processes occur within it and on whom the most representative decisions fall. That is, who are those who make 
up the Steering Committee of the Federation, i.e., who are the faces of the coffee elite. In this sense, it has been observed that although apparently participatory, the Federation has an established hierarchy that has been hardening and closing since the 1930s (DURÁN, 2008). This hierarchy "is determined by the ability to participate in the centers of choice to said decision centers, that is, by the power relations to access the choice of these centers" (VARGAS, 1996, p.12). Such power relations are established at all levels of the federation, from the Municipal Committees to the Steering Committee, in which the representativeness is determined by the place occupied in the local social configuration.

This coffee elite that transits between the local and the national spheres presents a place of established power firstly, determined by the advantages and monetary surpluses of the coffee crop, that is, an equivalent economic capital; but also extends to other fields and contributes to the accumulation of other types of capital, such as political, social and cultural, with which they are constituted as elite and differentiate themselves from the rest of the members of the organization. In other words, the elite acquires and constructs a commonplace, a habitus, in the words of Bourdieu, which transfigures and prolongs in time with the face of the NFCG, understanding Habitus as "systems of durable, transposable dispositions, structured structures predisposed to function as structuring structures, that is, as principles which generate and organize practices and representations (...)" (BOURDIEU, 1990 , p. 53). Such is the case that the previous regional hierarchical structures were institutionalized within the Federation to play an important role in deciding the horizons of coffee activity.

In this sense, when referring here to the Federation and its influence on foreign policy, we are referring to the elite that is in charge of the organization; those that come to compose the National
Congress of Coffee Growers and, more specifically, the Steering Committee, whose positions are decided due to political decisions and are perpetuated for different reasons and several mechanisms. As Vargas (1996, p. 12) states, "a co-opting mechanism has allowed certain notables of the departmental committees from the producing regions to be perpetuated by-election in the National Congress of Coffee Growers, a strategic center of system-related decisions". In other words, we are referring to power elite, which is "composed of men whose positions enable them to transcend the ordinary environments of ordinary men and women; they are in positions to make decisions having major consequences (...) they are in command of the major hierarchies and organizations of modern society" (Mills, 1956, p. 3-4).

\section{Coffee's Foreign Policy: the Role of the National Federation of Coffee Growers}

As the 20th century progressed, the NFCG began to acquire more strength and representation in the national scene with the creation of mechanisms for promotion, financing, and support of coffee activity.

One of the main instruments of the Federation that remains until today is the National Coffee Fund. This fund appeared because of the authorization given by Congress to manage all its revenues and was established by Decree-Law number 2078 of 22nd November 1940. In the beginning, it was a special account in the Bank of the Republic used to stabilize the coffee domestic price, that is, the price paid to producers, in order to face of international price shocks (PALACIOS, 2002). While, in the international scene, the country used the so-called Coffee Diplomacy, to establish commercial relations not only with coffee consuming countries or potential consumers, but also as a way of approaching other producing countries, main- 
ly Brazil, as a way to promote agreements, among the producers of the region, especially after the crisis of the 1930s. In this way, the Pan American Coffee Conferences are a clear example of events in which coffee diplomacy in Colombia was clearly reflected.

The background of these Conferences is related to the defense made by the delegation of Brazil during the London Economic Conference held in November 1933, where it wanted to study the bases of a possible agreement between the different coffee producing countries in order to limit the production and stabilize the prices (MANRIQUE, 2007). The acceptance by Colombia of Brazil's initiative was favorable, which is why, since then, the Colombian president of the time, López Pumarejo, together with the Colombian Consul General in London and later president of the National Federation of Coffee Growers, Alejandro López agreed that it was necessary to get closer to Brazil and to establish agreements (MANRIQUE, 2007).

The First Pan-American Coffee Conference (PACC) was convened by Colombia in 1936, which took place in Bogotá from October 5 to 10 of that year. As a result of this Conference, we had the creation of the Pan-American Coffee Office (PACO), formally created in January 1937, as well as laying the foundations for the subsequent concretion of the Inter-American Agreement on Export Quotas (AICE) (MANRIQUE, 2007).

The Pan-American Coffee Office emerges with the function of "executing and carrying out the decisions, agreements, and recommendations of said Conference and of those that meet with the same objective in the future" (ICEC, 1938, p. 63). It was decided to locate the Office outside the producing countries and, a consumer country was chosen as headquarters, which also facilitated access to information on the stock market and capital market. So, the Office "was properly installed in the building of 120 Wall Street in New York, half a block from the most active coffee business center" (ICEC, 1938, p. 63). What is striking in this fact is that, simultaneously, the National Coffee Department of Brazil and the National Federation of Coffee Growers of Colombia were transferred near to the PACO, "thus establishing a close collaboration between the representatives of these entities and the officials of this Office" (ICEC, 1938, p. 64).

In another side, Inter-American Export Quota Agreement (IAEQ), was signed in Washington on 28th November 1940. This agreement was formulated as a strategy to deal with the depressive phase of coffee prices that began in October 1939 as a consequence of World War II, that gradually places the United States as the sole commercial destination of coffee (AVELLA GÓMEZ, 2016). The IAEQ was made with the participation of delegates from 14 coffee exporting countries from Latin America and the Caribbean ${ }^{6}$, and delegates from one importing country, the United States, which at the time was already in the center of Colombia's foreign policy.

In this sense, the IAEQ had the objective of equitably distributing the United States market among the different coffee producing countries (Article 1 of the Agreement). In this way, it was sought to establish limits to exports of coffee to the United States, ensuring the proportional participation of Latin American coffee producers in the US market through the adaptation of supply to demand ${ }^{7}$ (AMERICAN STATES ORGANIZATION, 1940).

6 Brazil, Colombia, Costa Rica, Cuba, Ecuador, El Salvador, Guatemala, Haiti, Honduras, Mexico, Nicaragua, Peru, Dominican Republic and Venezuela.

7 The agreement not only established the export quotas for the United States market (Article 1 of the Agreement) but also set annual basic quotas for coffee export to markets outside the United States (Article 2 of the Agreement). In both cases, Colombia ranked below Brazil with 3,150,000 60-kg bags destined for the United States and 1,079,000 60-kg bags for other markets. 
Colombia was represented by Manuel Mejía Jaramillo a highly recognized coffee leader, known by the nickname of Mr. Coffee, who was the Manager of the NFCG since 1937 and would eventually go on to compose the diplomatic corps as Colombia's ambassador to the Brazil government. Mejía was responsible for negotiating the agreement on behalf of Colombia and to compose what would be the Inter-American Coffee Board. This fact is of vital importance in the course of this study because the Ministry of Foreign Affairs of Colombia directly commissioned to the Federation at the head of its Manager, to carry out a task that, in other countries, was developed by diplomats with experience in the area. In the case of Brazil, for example, it was Eurico Penteado who represented the country in this negotiation. Eurico began his career as an official of the Ministry of the Treasury, who later became part of the National Coffee Department (NCD) and ended up becoming a recognized diplomat in charge of Coffee negotiations abroad. He was head of the Brazilian delegations for the first five Pan-American conferences, president of the Pan-American Coffee Bureau and represented Brazil in the Inter-American Economic-Financial Consultative Committee in the capital of the United States (CPDOC, 2009).

The above reveals two different realities that are opposed. On the one hand, the presence of businessmen who due to their weight and influence on the national stage, claim places that interest them but do not belong to them -as is the diplomatic service- and presenting their interests as the interests of the State, that is, putting their interests as part of the National Interest. And on the other hand, there are the career bureaucrats who became specialists in a specific area -as the case of diplomats-, who move within the institutional structure of the State, coming to represent economic sectors in external affairs within the framework of State centrality.
The IAEQ ended up favoring the NFCG which used the need to intervene in the market to control a large part of the export of the grain, displacing foreign companies that had been controlling this business for more than 30 years (MACHADO, 1980). To supplement the commercialization activities, the NFCG created in mid-1940 (CÁRDENAS, 1993) the Grancolombiana Merchant Fleet, being the first company in the country to have its own maritime fleet for the international transportation of its products. In this way, the Federation controlled the value of freight -an important aspect in the calculation of the sale price-, freeing itself of the monopoly exercised by foreign companies such as "Grace Line, the United Fruit Company and the Gulf and South American Steamship, which in 1950 transported more than $60 \%$ of Colombian coffee" (MACHADO, 1980, p.156). An important aspect to highlight in relation to the Fleet is that it was created in consensus with other countries, like Venezuela and Ecuador, but the NFCG subscribed all the shares corresponding to Colombia (MACHADO, 1980) ${ }^{8}$.

In addition to the above, the economic activities of export and currency management carried out by the NFCG (VARGAS, 1996) allowed it to have an almost natural participation in the Coordinating Council of Foreign Trade, whose objective was to harmonize the plans, programs, and projects of the country in international economic matters, established through Decree 2901 of 1948 (MACHADO, 1980). This macroeconomic influence, articulated with the growing international projection and the expansion of coffee exports in the first half of the 20th century, led the Federation to establish direct relations with governments

\footnotetext{
8 Other instruments promoted by the Federation at this time to make coffee production viable were: The Coffee Bank at the beginning of the 50 's, the National Navigation Company, the Agricultural Insurance Company, the National Institute of Supplies and general warehouses for deposit.
} 
of other countries, such as the Government of Ecuador, with which it held loans for the payment of shares of the Merchant Fleet (MACHADO, 1980).

Finally, another important participation of the Federation in foreign trade policy of the country were through the creation of the Payment and Compensation Agreements. The NFCG used these agreements as mechanisms to send abroad "more coffee than traditionally sent to European and North American markets and at the same time intensify consumption in those countries, (...) in exchange for manufactured products or raw materials that the country needed "(MACHADO, 1980, p.57). These agreements were made through the Exchange Registry Office of the Bank of the Republic with support from the Ministry of Foreign Affairs and were very useful for the country and the coffee growers in times of difficulties, generated by the impacts of the Second World War (MACHADO, 1980).

\section{Conclusions}

The coffee exports represented the main source of Colombia's foreign currency during the first half of twenty century (DURÁN, 2008). Therefore, the National Federation of Coffee Growers had sufficient power to influence the direction of Colombian foreign trade of this time more than in the following decades. Hence, we see how the concessions made by the government to the NFCG not only limited to issues related to the national economy or the domestic market but on the contrary, extended to issues of foreign trade and world markets. This situation quickly turned the Federation in one of the most solid and tenacious pressure groups that the country has known (MACHADO, 1980), with the power of agenda to act in the formulation of economic, exchange and foreign policies.

Currently, there is even talks of an International Coffee Diplomacy which has been a key element of the Federation's strategy, allowing it to reposition coffee as a priority issue (SANTOS, 2002) and giving it the tools to participate in international negotiations that relate to its interest.

Finally and recognizing that, the economic affairs and, within this, the foreign trade makes an important part of the foreign policy of a country -as it is verified in the official page of Colombia Ministry of Foreign Relations-, it can be concluded that, The National Federation of Coffee Growers and its leaders, that is, the coffee elite, played an important role in the articulation of Colombia in the international market, contributing to the creation of the export profile and the "self-projection" (Goffman et al., 1997) of Colombia outside its borders. This image remains until today, being one of the characteristics that positively represent the role of Colombians in the world.

\section{References}

AMERICAN STATES ORGANIZATION (ASO). Inter-American Coffee Agreement. Washington, 1940. Available at: <http://www.oas.org/juridico/spanish/tratados/c-9. htm>. Accessed on: June 20, 2018.

AVELLA GÓMEZ, M. La economía colombiana en la Revista del Banco de la República, 1927-2015. Bogotá: Banco de la República, v. 1, 2016.

BECERRA, G. C. Los diplomáticos colombianos y la nacionalización de la Amazonia. Memoria y sociedad, v. 10, p. 51-68, 2007.

BOURDIEU, P. The Logic of Practice. Stanford: Stanford University Press, 1990.

CÁRDENAS, J. La industria del café en Colombia. Ensayos sobre Economía Cafetera, v. 6, n. 9, p. 3-15, 1993.

DURÁN, I. M. La federación nacional de cafeteros y la política cambiarla en Colombia 1923-1973: una aproximación historiográfica. Ensayos de Economía, v. 18, n. 32, p. 79, 2008. FALS-BORDA, O. La subversión en Colombia: visión del cambio social en la historia. Bogotá: Departamento de Sociología, Facultad de Ciencias Humanas, Universidad Nacional, 1967.

GOFFMAN, E.; LEMERT, C.C.; BRANAMAN, A. The Goffman reader. Cambridge, Mass.: Blackwell, 1997. 
INGLEHART, R.; WELZEL, C. Modernization, cultural change, and democracy: The human development sequence. Cambridge: Cambridge University Press, 2005.

KALMANOVITZ, S. Economía y nación: una breve historia económica de Colombia. Bogotá. Editorial Norma, 2003.

LOPES, D. B.; FARIA, C. A.; SANTOS, M. Foreign Policy Analysis in Latin American democracies: the case for a research protocol. Revista Brasileira de Política Internacional, Brasília, v. 59, n. 1, 2016.

MACHADO, A. La economía cafetera en la década de 1950. Cuadernos de Economía, Bogotá, v. 1, n. 2, p. 153232, 1980.

MANRIQUE, C. A. La diplomacia del café: estrategias político-económicas del Brasil y Colombia en los años treinta (1929-1940). Cali: Sello Editorial Javeriano, 2007.

INSTITUTO CUBANO DE ESTABILIZACIÓN DEL CAFÉ (ICEC). Segunda conferencia panamericana del café, celebrada en la Habana, agosto, 1937. Habana. Impresores Carasa, 1938.

MILLS, W. The Power Elite. New York: Oxford University Press, 1956.

Centro de Pesquisa e Documentação de História Contemporânea do Brasil (CPDOC). Verbete biográfico de Eurico Penteado. 2009. Available at: <http://www.fgv.br/cpdoc/acervo/dicionarios/verbete-biografico/penteado-eurico $>$. Accessed on: June 25, 2018.

PALACIOS, M. El café en Colombia, 1850-1970: Una historia económica social y política. Bogotá: Planeta, Ediciones Uniandes, El Colegio de México. 2002.

PUTNAM, R. D. Diplomacy and domestic politics: the logic of two-level games. International Organization, v. 42, n. 3, p. 427-460, 1988.

RATTON SANCHEZ, M. et al. Política externa como política pública: uma análise pela regulamentação constitucional brasileira (1967-1988). Revista de Sociologia e Política, Curitiba, v. 27, p. 125-143, 2006.

SALISBURY, R. Interest groups. In: POLSBY, N.; GREENSTEIN, F. (Orgs.). Handbook of political science. Bonston: Addison-Wesley, v. 4, 1975.

SALOMÓN, M.; PINHEIRO, L. Análise de Política Externa e Política Externa Brasileira: trajetória, desafios e possibilidades de um campo de estudos. Revista Brasileira de Política Internacional, Brasília, v. 56, n. 1, 2013.

SAETHER, S. Café, conflicto y corporativismo una hipótesis sobre la creación de la Federación Nacional de Cafeteros de Colombia en 1927. Anuario colombiano de historia social y de la cultura, Bogotá, n. 26, p. 134-163, 1999.

SANTOS, J. M. El café en la agenda internacional. Ensayos sobre Economía Cafetera, v. 18, p. 9-14, 2002.

TUCKER, C. M. Coffee culture: local experiences, global connections. New York: Taylor \& Francis, 2017.

URRUTIA, M. et al. Comercio exterior y actividad económica de Colombia en el siglo XX: Exportaciones totales y tradicionales. Bogotá: Banco de la Republica de Colombia. 2000.

VARGAS, F. R. Las organizaciones del sector cafetero colombiano. Revista Innovar Journal Revista de Ciencias Administrativas y Sociales, Bogotá, n. 7, p. 7-26, 1996.

WOOLCOCK, S.; BAYNE, N. What is Economic Diplomacy? In: WOOLCOCK, S.; BAYNE, N. (Eds.). The New Economic Diplomacy: Decision Making and Negotiation in International Economic Relations. Farnham, England. Ashgate Publishing, Ltd., E-book. 2011, p. 1-17. 